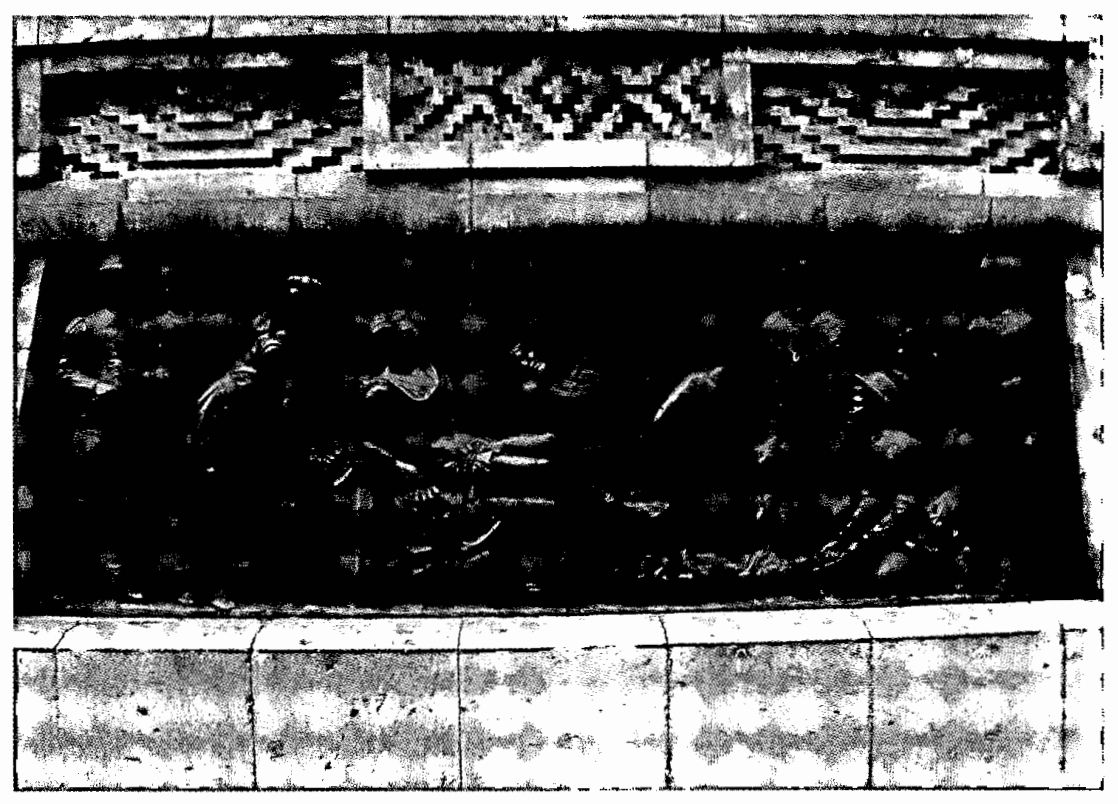




\section{Rogelio Jiménez Marce}

Maestro en Historia por el Instituto Mora. Estudiante de doctorado en el Centro de Investigaciones y Estudios Superiores en Antropología Social. Sus áreas de interés son la historia cultural, la historia intelectual, la historiografía y la historia de los pueblos indios. Ha publicado La pasión por la polémica. El debate sobre la bistoria en la época de Francisco Bulnes, Instituto Mora, México, 2003, y "La creación de una genealogía liberal", Historias, INAH, núm. 51, enero-abril, 2002, México.

\section{Resumen}

Este artículo analiza el imaginario de algunos pensadores del siglo XIX acerca de la diversidad racial existente en el país. Para los intelectuales liberales era necesario conseguir una homogeneidad racial, la cual era uno de los pasos necesarios para alcanzar el progreso de México. Ellos pensaban que la homogeneidad se podía lograr por medio de la educación y la mezcla racial. Es por esto que el "mestizo" se convirtió en el representante ideal de la unidad e identidad nacional, pues en él se encontraban fusionados los valores de las razas indígena y española. Así, el mestizo se convirtió en el prototipo ideal del mexicano.

Palabras clave:

Historia intelectual, indígenas en el siglo XIX, evolución, raza, ideas sobre mestizaje.

\section{Abstract}

This article analyzes the ideas of certain $19^{\text {th }}$ century thinkers on the country's racial diversity. Liberal intellectuals felt it was essential to achieve racial homogeneity, regarded as a crucial step in the progress of Mexico. They thought that homogeneity could be achieved through education and racial interbreeding. This is why the mestizo became the ideal representative of national unity and identity, since he combined the values of the indigenous and Spanish races. Thus, the mestizo became the ideal prototype of the Mexican.

\section{Key words:}

Intellectual history, indigenous people in the $19^{\text {th }}$ century, race, ideas on miscegenation.

Fecha de recepción:

diciembre de 2002

Fecha de aceptación: octubre de 2003 


\title{
La construcción de las ideas sobre la raza en algunos pensadores mexicanos de la segunda mitad del siglo XIX
}

\author{
Rogelio Jiménez Marce*
}

Irene Mata Vélez (in memoriam)

$\mathbf{E}$ n una fotografía tomada a principios del siglo $\mathrm{XX}$, se observa una escena que nos permite introducirnos a la forma como se concebía al otro. Cuatro figuras masculinas dominan la escena. Dos de ellos se encuentran parados sobre una banca y miran impasibles a las personas que se congregan a su alrededor. Lo peculiar de esos dos hombres es la forma como están vestidos. Los dos tienen ropas de cuero, carecen de zapatos y tienen una gran banda adornada con plumas que les rodea la cabeza; tienen el pelo largo y adornan su nariz con un gran aro de metal. El individuo de la izquierda sostiene entre sus manos un tambor. Los otros dos personajes se encuentran ubicados a ambos lados de la banca en la que se exhibe a esos hombres. El sujeto de la derecha sostiene entre sus manos un altavoz, en tanto que el de la izquierda tiene levantada su mano derecha y la dirige hacia uno de los individuos, en actitud de mostrar al espectador que el punto al que debe enfocar su atención es a ese hombre diferente. La carpa levantada al fondo del

\footnotetext{
* Agradezco las sugerencias realizadas por los dictaminadores del trabajo.
}

cuadro y una gran manta nos permiten saber que los dos individuos de la banca son indios "somma apaches", los cuales son exhibidos en un circo por su asombrosa capacidad para manipular serpientes venenosas y otras acciones que no realizan los hombres "civilizados" (véase imagen 1).

Lo interesante de la foto es que reproduce una de las imágenes estereotipadas de los grupos que conformaban la sociedad mexicana de finales del siglo XIX. Los apaches eran considerados uno de los grupos "salvajes". Ello explica la razón por la que se los exhibía como atracción circense. Hay que mostrar lo que es diferente a nosotros para exhibir el atraso en el que viven los demás. Es pertinente señalar que en la sociedad mexicana se habían creado una serie de estereotipos que buscaban presentar cómo eran los distintos grupos indígenas, los mestizos, los criollos y los extranjeros. Esa serie de imágenes nos puede ayudar a entender los parámetros que delineaban la realidad y la manera como se la percibía. Ese "retrato" de la sociedad se constituyó a partir de la puesta en escena de una serie de discursos, tanto escritos como visuales, que conforman 


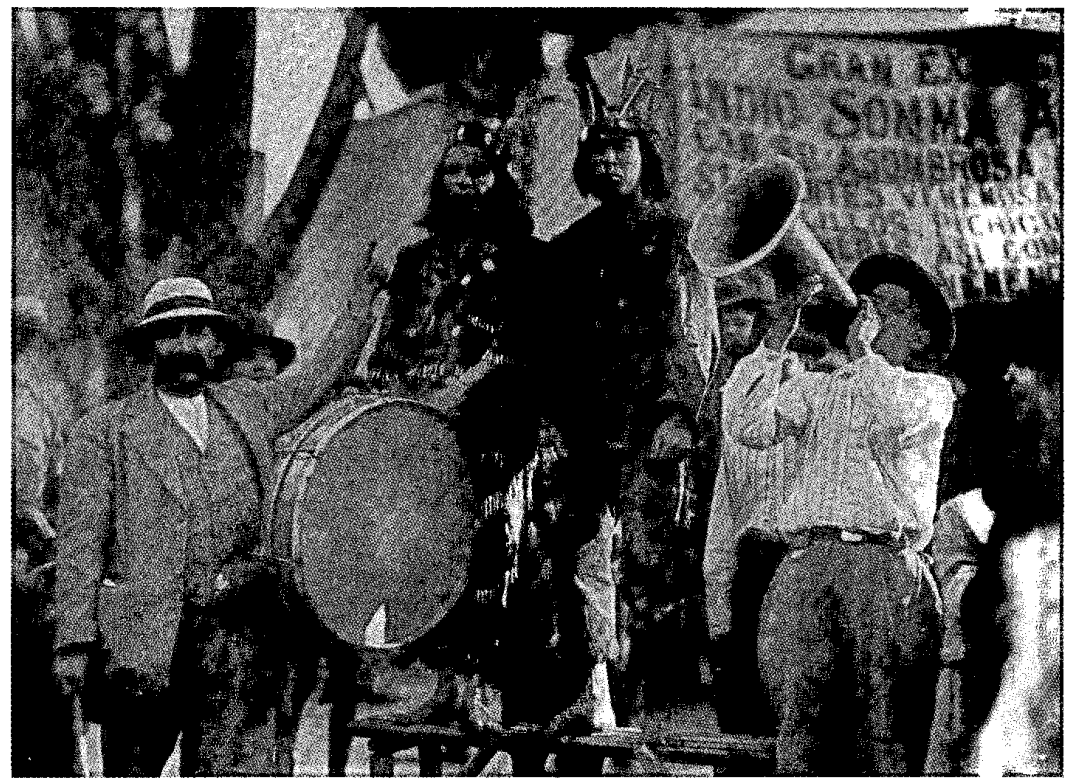

Imagen 1. Publicada en Blanco, Espejos, 1998, p. 24.

un "mundo de imágenes"1 instituido por los pensadores liberales. En ellos se revela la naturaleza social de la visión y de la representación, misma que buscaba consolidar la imagen del "mestizo" como el fac-

${ }^{1}$ Poole, Visión, 2000, p. 15. Deborah Poole señala que el "mundo de imágenes" se debe entender como la combinación que se realiza entre las relaciones de referencia e intercambio de las propias imágenes con las de carácter social y discursivo. Ello permite comprender la vinculación entre aquellos que elaboran imágenes y los que las consumen. El "mundo de imágenes" nos muestra cómo las representaciones fluyen de un lugar a otro, de una persona a otra y de una cultura a otra. Además de que nos ayuda a juzgar de manera crítica la política de la representación. tor primordial de constitución e identidad de los mexicanos. Este trabajo busca analizar la forma en que se originó ese "mundo de imágenes" de la sociedad mexicana de finales del XIX. Para ello se analizan las ideas de Francisco Pimentel, Justo Sierra, Francisco Bulnes, Agustín Aragón, Genaro Raigosa y Andrés Molina Enríquez.

Estos personajes pertenecían a tres generaciones diferentes $y$, por lo mismo, tenían distintas preocupaciones políticas y diversas premisas teóricas. Pimentel era un hombre que estuvo vinculado durante un tiempo al imperio de Maximiliano. Publicó sus ideas sobre los indígenas en 1864 en su Memoria sobre las causas que ban originado la situación actual de la raza 
indígena y medios de remediarla. Aragón, Bulnes, Raigosa y Sierra eran intelectuales afiliados al positivismo y tenían estrechas relaciones con el régimen de Porfirio Díaz. Bulnes editó sus planteamientos sobre la raza en 1899 en El porvenir de las naciones latinoamericanas ante las recientes conquistas de Europa y Norteamérica, mientras que Aragón, Sierra y Raigosa lo hicieron al amparo del México: su evolución social, obra publicada entre 1900 y 1902 y que enaltecía el progreso del país bajo la presidencia de Porfirio Díaz. Finalmente, Molina Enríquez también estaba afiliado al positivismo, pero mostraba cierta oposición al régimen porfiriano. Sus ideas sobre el mestizaje aparecieron en 1909 en Los grandes problemas nacionales. Analizar las ideas de estos hombres nos permite acceder a una etapa de la historia del pensamiento mexicano en la que se puso mayor énfasis en el problema indígena y en la construcción de una "representación" del México "mestizo".

Entender la visión que las elites tenían de cada uno de los grupos étnicos que componían la sociedad mexicana nos puede ayudar a comprender el imaginario racial que construyeron los intelectuales mexicanos de finales del siglo XIX y principios del xx. Un asunto que se debe destacar es que la profundidad de las ideas varía en cada uno de los autores analizados. Así, mientras Pimentel dedicó la mayor parte de su atención al asunto indígena, Molina Enríquez hizo una notable evaluación del mestizaje. Los otros autores repartieron sus intereses entre las dos cuestiones, es decir, trataron de explicar tanto la cuestión indígena como el mestizaje. Sin embargo, todos los autores buscaban encontrar soluciones al problema de la diversidad étnica. El estudio que a continuación presentamos se divide en dos partes. En la primera se presentan las distintas perspectivas que se tenían sobre el "problema indígena". Se hace una revisión de las causas que, desde el punto de vista de estos autores, habían generado la degradación del indígena y las posibles soluciones para integrarlos al progreso nacional. En la segunda parte se aborda la forma en que los intelectuales liberales propusieron un discurso en el que el mestizo se convirtió en el prototipo de identidad para el mexicano decimonónico.

\section{LOS DILEMAS DEL INDÍGENA. \\ EN'TRE UN PASADO GLORIOSO Y UN PRESENTE DE INTEGRACIÓN}

En la mayoría de las representaciones de los intelectuales decimonónicos liberales existe una doble lógica para referirse a los indígenas. Por un lado se alababa su pasado "glorioso", y, por el otro, se los denostaba por el atraso en el que se encontraban, y se buscaban soluciones para superarlo. Respecto a la primera posición, se situaba a la historia antigua de México como el principio de la genealogía nacionalista liberal. Si un rasgo caracterizó a la historia antigua de México es que ésta se construyó en torno a la grandeza de la "dinastía" azteca. Una monarquía que, según los historiadores, tuvo como antecesores a los toltecas y a los chichimecas, quienes depositaron todo su saber en ellos. ${ }^{2}$ Con base en este argumento se planteó la cuestión de la sucesión directa en torno a una herencia histórica que le

2 Véase Escandón, "Historia", 1988, pp. 35-38. Para la construcción de la genealogía liberal consúltese Jiménez, "Construcción”, 2002, pp. 26-28. 
dio legitimidad al pueblo azteca. La historia concebida de este modo era una historia lineal que tendía al progreso continuo en dirección a un desarrollo perfecto de los pueblos. Esta forma de construir la historia bajo la idea de un legado indígena es propia de lo que Benedict Anderson llama la "segunda generación nacionalista". Anderson señala que los nacionalistas "aprendieron a hablar 'por' [los] muertos con los que era imposible establecer una conexión 'lingüística'".

Esto fue lo que llevó a la aparición del "indigenismo" y a que los intelectuales de filiación liberal rastrearan sus orígenes en el pasado indígena y no en el español. Es la crèación de "recuerdos" que, según Peter Burke, busca dar significado a ciertos acontecimientos importantes para el grupo. En este sentido, Gavin Smith y Gerald Sider destacan que la "conmemoración" reclama e impone un pasado al futuro y una representación frente al otro. Ello muestra la profunda ambivalencia que tienen las sociedades modernas con respecto al pasado. Ambivalencia que es reproducida por las nuevas instituciones políticas, mismas que tienen la tarea de crear "recuerdos públicos" que estén asociados con la memoria física. Los símbolos conmemorativos invocan un sentido de "recuerdo" más que de "igualdad" entre los individuos. Burke menciona que los grupos sociales construyen sus recuerdos, determinan lo que es lo "memorable" y cómo debe ser evocado. ${ }^{3}$ En este sentido, es interesante la explicación que presenta-

${ }^{3}$ Véase Anderson, Comunidades, 1993, p. 96, y "Efecto", 1992, pp. 96, 103; Burke, Formas, 1999, pp. 66, 71-72, 79; Smith y Sider, "Introduction", en History, 1997, pp. 8, 17; Smith, "Pandora's", 1997, pp. 87, 93. Peter Burke y Gavin Smith coinciden en ron los intelectuales liberales sobre los aztecas, el pueblo indígena que, desde su perspectiva, representaba con mayor dignidad a la antigüedad mexicana. Esta visión tenía algunas particularidades, mismas que se incorporaron a la percepción global de la historia que se nos legó.

En algunos escritos de los pensadores liberales se postulaba la idea de que los mexicas eran los dirigentes de una nación constituida en el momento de la llegada de los españoles. Con ello se asimilaba a todos los grupos indígenas bajo su dominio y se fortalecía la idea de un poder central presente en ese momento histórico. De tal forma que hablar del pasado indígena era hablar del pasado azteca, el cual se concebía como el auténtico pasado mexicano y el precedente de la nación mexicana moderna. ${ }^{4}$ En el imaginario histórico liberal, el prototipo del indígena fue Cuauhtémoc, quien había alcanzado el atributo de héroe por la defensa que realizó contra los conquistadores españoles. A este

que los "recuerdos" o "conmemoraciones" se ven afectados por la organización social de la transmisión y por los medios empleados por la misma.

${ }^{4}$ Tenenbaum, "Streetwise", 1994, pp. 137, 141; Lafaye, "Prolegómenos", 1994, pp. 30-31; Ferrer y Bono, Pueblos, 1998, p. 119; Tenorio, Artilugio, 1998, pp. 106, 116; Smith, "Pandora's", 1997, p. 84. De ello podía dar cuenta la composición del monumento que se erigió a Cuauhtémoc, en el que se buscó representar a toda la nación a través de la inclusión de elementos de otros grupos étnicos. Así, en la base del monumento se pueden apreciar motivos mayas y zapotecas. Este carácter arbitrario tendía a crear una tradición gloriosa. Otro ejemplo es el Palacio Azteca que se presentó en la Exposición Universal de París en 1889. Estos dos hechos nos muestran cómo se construye lo que Gavin Smith llama "una memoria complaciente", misma que sirve para ocultar o ensalzar ciertos hechos de la historia. 
personaje lo asociaron con virtudes como la "superioridad moral", la "gallardía" y una gran capacidad guerrera. ${ }^{5}$ Ahora bien, Agustín Aragón ${ }^{6}$ señalaba que la glorificación del pasado prehispánico tenía el propósito de enseñar a los indígenas vivos que ellos podían mejorar su porvenir. Eso se lograría a partir de que éstos se reconocieran como los herederos de civilizaciones que habían alcanzado un alto nivel cultural. Aragón tenía la esperanza de que un "brillante" estado anterior los incentivara a mejorar sus condiciones presentes. ${ }^{7}$

La existencia de un pasado glorioso no ayudaba a explicar cómo es que se ha-

${ }^{5}$ Sierra, Evolución, 1991, t. Xu, p. 68; Crespo, "Evolución", 1902, p. 57; Pimentel, Memoria, 1903, t. III, p. 59; Burke, Formas, 1999, p. 75. Burke señala que la "mitogénesis" busca crear lazos de identificación entre los individuos y el estereotipo del héroe. Esa coincidencia cautiva la imaginación de la gente, la cual comienza a crear historias en torno a ese individuo. Ello podría explicar por qué Francisco Pimentel decía que Cuauhtémoc se diferenciaba de los demás indios porque tenía un "color más claro". Aparte del obvio enfoque racial, también existe un afán de crear "historias" referentes a él.

${ }^{6}$ Agustín Aragón nació en Morelos en 1870. Ingeniero de profesión ocupó algunos puestos en la administración porfirista, mismos que abandonó para afiliarse a la oposición política al régimen. Miembro del Comité Antirreeleccionista. En el gobierno de la Convención fue nombrado secretario de Fomento. Editor de la Revista Positiva y autor de diversos estudios históricos y filosóficos como A. D. Xenopol y el Sr. Lic. D. Antonio Caso (1920) y Porfirio Díaz (Estudio histórico-filosófico) (1962).

${ }^{7}$ Aragón, "Población", 1902, pp. 25-28. Véase también Sierra, Evolución, 1991, p. 44; Tenorio, Artilugio, 1998, p. 114; Реña, "Empeño", 1992, p. 129; Cramaussel, "Imagen", 1998, p. 351. Esa misma idea la compartían Justo Sierra y Alfredo Chavero, quienes pensaban que el ejemplo de los antiguos aztecas podía ayudar a mejorar las decaídas razas indígenas. bía producido la decadencia de los pueblos indígenas. Varias explicaciones se postularon para aclarar ese hecho. En primer lugar, se señalaba la diversidad de razas que poblaban el territorio. Desde la época prehispánica se habían establecido numerosas tribus indígenas que ocupaban demarcaciones distintas, hablaban lenguas diferentes y tenían diversos grados evolutivos, mismos que se podían ubicar en tres categorías: civilizados, semicivilizados y salvajes. Aunque sus características evolutivas y étnicas eran diversas, eso no fue visible para los conquistadores españoles, que los ubicaron a todos en un mismo esquema. Esto fue contraproducente para los indígenas más civilizados, pues el contacto con seres de menor cultura propició un notable retroceso en ellos. Muchos de éstos se mezclaron con las razas "atrasadas", con lo que experimentaron un proceso de involución hacia el salvajismo y la barbarie. Ese proceso se aceleró con la disolución de las grandes poblaciones y su necesidad de establecerse en condiciones desfavorables. Así, se podía explicar por qué había tal diversidad de pueblos que mostraban tantas variaciones entre ellos. Todo formaba parte de un mismo proceso histórico que había favorecido las desigualdades. $^{8}$

${ }^{8}$ Pimentel, Memoria, 1903, p. 8; Molina, Grander, 1981, pp. 90-93; Raigosa, "Evolución", 1902, pp. 6, 16; Sierra, Evolución, 1991, pp. 54, 75, 109; Tenorio, Artilugio, 1998, pp. 125, 138. En Monografías de arqueología mexicana: Teotihuacán; o la ciudad sagrada de los aztecas, Leopoldo Batres señalaba que en la gran variedad de razas que habían poblado el país se podía encontrar la principal causa que había ocasionado que una raza apta para la evolución, como lo era la azteca, detuviera su proceso de desarrollo. Ello originó una paradoja, pues el pueblo azteca cra poderoso pero estaba degenerado en su interior. 
En segundo lugar, se explicaba su decadencia como parte de un proceso interno que había comenzado durante la época prehispánica y que había pasado de generación en generación como parte de una herencia racial. Francisco Pimentel ${ }^{9}$ pensaba que ese proceso interno de degeneración era lo que explicaba las contradicciones que se daban en todos los órdenes de la vida de los pueblos indígenas. Esto se ponía de manifiesto en el hecho de que habían alcanzado grandes conocimientos matemáticos, pero no habían construido instrumentos que los ayudaran en su vida diaria. En el ámbito político, no se podía entender cómo es que existía una forma republicana de gobierno como el senado tlaxcalteca y, al mismo tiempo, floreciera una cruel tiranía como la azteca. Tampoco se podía explicar cómo es que tenían leyes severas para castigar a los hombres, pero no se concibiera un infierno brutal para los infractores. Por último, era difícil comprender cómo es que tenían una religión "bárbara" basada en los sacrificios humanos, pero en la que también se contemplaba una moral pura y generosa. Pimentel pensaba que la imperfecta evolución

\footnotetext{
${ }^{9}$ Francisco Pimentel nació en 1832 en Aguascalientes. Desempeñó algunos puestos políticos durante el imperio de Maximiliano. Realizó estudios lingüísticos y literarios como Cuadro comparativo y descriptivo de las lenguas indigenas de México (18621865); Historia crítica de la poesía en México (1883). Presidió el Liceo Hidalgo. Una de sus obras más importantes fue Memoria sobre las causas que han originado La situación autual de la raza indígena y medios para remediarla, misma que apareció, a decir de Hale, en un momento en el que había una gran indiferencia de conservadores y liberales sobre el problema indígena. Sin embargo, la evaluación pesimista de Pimentel no generó comentarios de sus contemporáneos. Véase Hale, Transformación, 1992, pp. 361-362.
}

de los pueblos indígenas explicaba, en buena medida, su decadencia. ${ }^{10}$

Su religión sólo les endureció el corazón y les había inspirado ideas degradantes acerca de la humanidad. El despotismo de su gobierno los acostumbró a obrar con temor y a no tomar sus propias decisiones. Ello contribuyó a que se volvieron "tímidos", "irresolutos", "hipócritas" y "desconfiados". Su sistema de educación los llevó al abatimiento y a la abyección. Su falta de conocimiento del derecho de propiedad privada les impidió conocer la libertad individual. ${ }^{11}$ Pimentel consideraba que el segundo elemento que ayudó a la degradación indígena fue la dominación española. La guerra de Conquista había producido la destrucción de los pueblos prehispánicos. Los españoles no se preocuparon en respetar sus leyes, sus costumbres o su forma de gobierno, por lo que el choque cultural dejó una

${ }^{10}$ Pimentel, Memoria, 1903 pp. 44-48. Pimentel señalaba que esa "imperfecta evolución del espíritu" se había manifestado en todas las épocas y en todos los países. Ello servía para explicar por qué naciones antiguas como Roma, Grecia, Fenicia, Persia y Arabia presentaban este mismo tipo de contrastes. Es por esta razón que Pimentel pensaba que la civilización era un fruto tardío que se podía recoger después de muchos afanes. Así, las "aberraciones" de los indígenas no eran una obra exclusiva de ellos, sino que las compartían con toda la humanidad.

${ }_{11}$ Molina, Grandes, 1981, p. 109; Raigosa, "Evolución", 1902, p.9. Genaro Raigosa y Andrés Molina coincidían en que uno de los grandes males de los indígenas era su carácter sumiso, pasivo e incondicional que había sido producto del despotismo en el que vivían. Por ello es que Raigosa decía que cuando los conquistadores les concedieron la "igualdad", ellos cayeron en una "inercia sistemática" que los condujo a la desintegración y a una regresiva evolución, pues no sabían cómo actuar sin la presión de un poder que los oprimiera. 
profunda herida que fue difícil de restañar. El establecimiento de la esclavitud provocó su aniquilamiento moral, la pérdida de la esperanza y su envilecimiento. La evangelización no había rendido los frutos que se esperaban y por eso los indígenas habían conservado sus antiguas creencias idolátricas. En este sentido, la religión católica se presentaba como un elemento de progreso que no fue aprovechado por los nativos. ${ }^{12}$

Pimentel señalaba que las leyes de Indias no cumplieron con el papel de ayudar al crecimiento moral de los indígenas, sino que los sumieron en una "infancia perpetua", ${ }^{13}$ en la "brutalidad", en el aislamiento, en la desmoralización y en la total degradación. Agustín Aragón también creía que la conquista había detenido la marcha ascendente de los indígenas hacia la civilización, pues los hispanos no hicieron nada para ayudar al pleno desenvolvimiento de los pueblos vencidos. Si los españoles hubieran cumplido con su papel, los indígenas habrían alcanzado un desarrollo distinto, tal y como se podía comprobar con los indígenas que habían sido educados. Ellos habían demostrado lo que se podía hacer con su raza. La falta de atención de los españoles hacia los indígenas tuvo como consecuencia que éstos

${ }^{12}$ Pimentel, Memoria, 1903, pp. 48-51; Aragón, "Población", 1902, p. 26. Agustín Aragón pensaba que poner a los indios bajo la tutela del clero sólo contribuyó a que no se los viera como elementos útiles de la sociedad.

${ }^{13}$ Hale, Transformación, 1992, p. 363. El concepto de "infancia perpetua" daba cuenta de una vinculación entre el indígena y el niño, con to que se buscaba justificar la degradación supuesta o real del primero. Sierra explicaba, en 1893, que el indígena era un "menor perpetuo" debido a la excesiva protección que le confirieron los españoles. adquirieran un carácter pacífico, benévolo, obediente y retraído, lo cual restaba cualquier posibilidad de acción. ${ }^{14}$ Resulta interesante destacar que Pimentel y Aragón coincidían respecto a que no se podía juzgar a los españoles por sus errores, sino que más bien se debería tratar de entender por qué las medidas que ellos tomaron no dieron los resultados que se esperaban.

Por otra parte, Genaro Raigosa ${ }^{15}$ consideraba que la degeneración indígena era un producto de las carencias que se habían manifestado desde tiempos remotos. Las civilizaciones indígenas carecían de medios de comunicación, de industria, de moneda, de comercio en gran escala y de animales que los ayudaran en el trabajo. Todo lo anterior había condicionado el pleno desenvolvimiento de las culturas. Ello se evidenciaba en el hecho de que habían sido conquistados por su escaso conocimiento de los metales. Justo Sierra ${ }^{16}$ adu-

${ }^{14}$ Pimentel; Memoria, 1903, pp. 61-114; Aragón, "Población", 1902, pp. 23, 27-28; Molina, Grander, 1981, p. 109; Flores, Historia, 1982, t. II, 1p. 449-450. Por otra parte, Molina Enríquez y Flores y Troncoso consideraban que el atraso indígena era producto de la esclavitud española, la cual sólo sirvió para minar las fuerzas de los nativos, lo que llevó a su fin irremediable.

${ }^{15}$ Genaro Raigosa nació en Zacatecas en 1847. Diputado y senador por San Luis Potosí en varias ocasiones. Fue ministro plenipotenciario para negociar el Tratado de Comercio y Navegación con el imperio alemán. Agente financiero de México en Londres. Fue miembro de varias asociaciones de jurisprudencia.

${ }^{16}$ Justo Sierra nació en Campeche en 1848. Escribió en varios periódicos. Fue diputado, magistrado de la Suprema Corte de Justicia, subsecretario y ministro de Instrucción Pública y ministro plenipotenciario de México en España. Entre sus obras destacan, Evolución política del pueblo mexicano y Juárez: su obria y su tiempo. 
cía que la conquista española fue una consecuencia palpable de la atrofia que experimentaban las facultades de los pueblos indígenas. Por ello es que Sierra consideraba que este suceso había sido favorable, pues había contribuido a reemplazar una - evolución lenta por una de tipo superior. Sin embargo, la política aislacionista establecida por la corona contribuyó a acentuar el atraso de los indígenas y a que éstos mostraran una gran resistencia a integrarse a la civilización. Sierra pensaba que el único medio que podía ayudar a los indígenas a salir de la decadencia era el proceso de asimilación a la nueva cultura, lo cual se podía realizar a través de la mezcla racial. ${ }^{17}$

Francisco Bulnes ${ }^{18}$ pensaba que los indígenas se resistían a civilizarse debido a que siempre habían tendido a la inmutabilidad y a la pasividad. Ellos no eran una raza "progresista", razón por la cual no buscaban su mejoramiento material, intelectual y moral. Bulnes creía que ello se debía a su tipo de alimentación. Los indígenas comían maíz. Este cereal no era el más adecuado para desarrollar una alta cultura, aunque sí era mejor que el arroz. Bulnes señalaba que para crear una gran civilización se debería consumir trigo. Cereal que se presentaba como el más progresista de todos. Bulnes destacaba

\footnotetext{
${ }^{17}$ Raigosa, "Evolución", 1902, p. 8; Sierra, Evolución, 1991, pp. 30, 38, 96, 109, 169.

${ }^{18}$ Francisco Bulnes nació en la ciudad de México en 1847. Ingeniero de profesión. Escribió en varios periódicos. Diputado por Morelos. Miembro de diversas comisiones legislativas. Escribió varios libros que causaron una gran polémica en su momento como Las grandes mentiras de nuestra bistoria (1904); El verdadero Juárez $y$ la verdad sobre la intervención y el imperio (1904); El verdadero Díaz y la revolución (1920).
}

que la carencia de gallinas, vacas y cabras había provocado que la alimentación de los indígenas fuese más reducida. Si una raza tenía una mala alimentación, entonces no se la podía culpar por su "barbarie", ni por su natural decadencia. Desde esta perspectiva, no resultaba extraño que los indígenas hubieran sido conquistados. Bulnes advertía que si bien era cierto que los conquistadores habían introducido animales, trigo y hierro, ellos no se habían preocupado por mejorar las condiciones de vida de los indígenas, quienes habrían evolucionado si su dieta hubiera incluido una alimentación más completa. Pero como ello no se produjo, entonces los individuos se tuvieron que adaptar a condiciones inferiores de vida. Esto había provocado la paralización de sus ideales y de su imaginación. ${ }^{19}$

La mayoría de los intelectuales estudiados reconocían que la situación de los indígenas no había variado después de la independencia, movimiento en el que ellos no tuvieron una participación destacada. Aunque se había declarado la igualdad entre indígenas y blancos, lo cierto es que faltaba mucho tiempo para que ese sueño se hiciera realidad. Las constantes guerras civiles y las invasiones extranjeras habían detenido las propuestas que se presentaban a fin de mejorar sus condiciones. Lo peor de todo es que ellos se habían visto obligados a participar en las guerras civiles debido a que los partidos los tomaban como "carne de cañón" para sus ejércitos. Aragón decía que con el gobierno de Díaz se había logrado establecer un periodo de paz, con lo que se presentaba la ocasión idónea para integrarlos a la evo-

${ }^{19}$ Bulnes, Pomenir, s. a., pp. 9-10, 19, 25, 27. 
lución del país, pues no se podía pasar por alto que los indígenas eran la "masa principal de la población", no sólo en número sino también como fuerza social. Es por eso que no se podía prescindir de ellos, pues eso equivaldría a despreciar los elementos más importantes del conglomerado social. Sin embargo, Aragón estaba consciente de que existía un gran desprecio por el indígena, al grado de que algunas personas le habían comentado que se degradaban con el simple hecho de "pensar en ellos". 20

Aragón consideraba esta opinión como "una vulgaridad de juicio y una falta absoluta de moralidad" hacia unos grupos humanos que eran capaces de civilizarse. Además de que ellos constituían el verdadero punto de apoyo social y de existencia material, pues sin su trabajo México no saldría adelante. Esta opinión hacía evidente que tenía una posición antidarwinista respecto al problema indígena. Reconocía que ellos eran grupos atrasados, pero postulaba que eran capaces de integrarse al desarrollo de la nación moderna. Aragón buscaba modificar la opinión común de que todos los indios eran "levantiscos", "incivilizados" y "viciosos", opinión que se encontraba en la mayoría de los periódicos de la época. En ellos se mencionaba que el carácter "bárbaro" y "salvaje" de los nativos afectaba la prosperidad de ciertas regiones del país. Aunque esa opinión se generalizaba para todos los grupos indígenas, lo cierto es que también se reconocía que éstos se encontraban

${ }^{20}$ Aragón, "Población", 1902, p. 26; Bulnes, Porvenir, s. a., p. 96; Sierra, Evolución, 1991, p. 97; Hale, Transformación, 1992, pp. 360, 363. Bulnes y Sierra creían que la integración del indígena serviría para enaltecer el patriotismo mexicano. ubicados en tres grandes grupos: los "civilizados", los "semicivilizados" y los "salvajes". Al último grupo pertenecían los apaches. Por ello no es extraño que la descripción de la fotografía que se presentó al principio del texto hiciera referencia a ellos como unos "incivilizados". Esa era la imagen que ciertos grupos sociales tenían de los indios del norte del país. ${ }^{21}$

Otra muestra de ello se encuentra en el México: su evolución social, libro dirigido por Justo Sierra y publicado entre 1902 y 1903, en el que se trataba de mostrar el desarrollo evolutivo por el que había pasado el país hasta ese momento. Esto con la intención de mostrar cuál era el proyecto de modernidad que México tenía para el presente y para el futuro. Es por ello que se puede ver este libro como un ensalzamiento del régimen de Porfirio Díaz. Los materiales gráficos que se presentaban en ese texto incluían fotografías y litografías de algunos de los grupos raciales que conformaban México. La litografía que hacía referencia a los indios "tarahumares" tenía un gran impacto visual. Se los mostraba como unos hombres semidesnudos que sólo ocupaban unos pedazos de tela para cubrirse. Se hacía énfasis en su carácter hostil. $\mathrm{Al}$ igual que los "salvajes" apaches, ellos también llevaban el pelo largo, hacían uso del arco y la flecha para conseguir su alimento. Síntoma que evidenciaba con claridad su atraso evolutivo. El que se les pusiera en un lugar despoblado evidenciaba su carácter nómada. Así, el atraso, la hostilidad y el nomadismo eran los factores que

${ }^{21}$ Aragón, "Población", 1902, p. 30. Para la opinión periodística sobre los indígenas véase Rojas, Indio, 1987; Escobar y Rojas, Presencia, 1992; Ferrer y Bono, Pueblos, 1998, pp. 572 y ss. 
caracterizaban a estos indígenas (véase imagen 2). ${ }^{22}$

En el grupo de los semicivilizados se ubicaba, entre otros, a los yaquis, a los mayos y a los lacandones. Éstos se diferenciaban de los "salvajes" debido a que tenían algunos conocimientos de las artes mecánicas. Sin embargo, ellos buscaban vivir en comunidades aisladas, en las que podían aplicar sus usos y costumbres antiguos, entre los que destacaban la idolatría y la superstición. Mostraban habilidad en las obras manuales y de imitación, pero se aferraban a su forma de vida. Prueba de ello era que todavía hablaban su idioma. La mayoría de ellos eran siervos, y sus mayores vicios consistían en el robo y la embriaguez. El tetcer grupo estaba conformado por las poblaciones indígenas que ocupaban la meseta central del país. Estos eran los individuos a los que se buscaba integrar en el proyecto de nación. De este tipo de indígena se hicieron algunas descripciones que insistían en sus características físicas y morales. Francisco Pimentel decía que eran seres taciturnos, graves, melancólicos, flemáticos, fríos, sufridos, resignados, serviles, desconfiados, hipócritas, tímidos, mentirosos, pérfidos, pródigos, lentos en la elaboración de su

${ }^{22}$ La presencia de una litografía en lugar de una fotografía evidenciaba el "salvajismo" de estos grupos indígenas, pues no se los había podido retratar y sólo se podía mostrar su presencia por medio de ilustraciones. Este hecho los diferenciaba de los grupos indígenas "civilizados", a quienes sí se les podía tomar fotografías. Ahora bien, este tipo de litografía tenía una carga antropológica colonialista, es decir, buscaba mostrar al "salvaje" que se debía colonizar. Dentro de la composición del texto, la litografía ocupaba un lugar secundario. De hecho, tenía una dimensión menor que la que estaba destinada a las fotografías de los indígenas "civilizados".

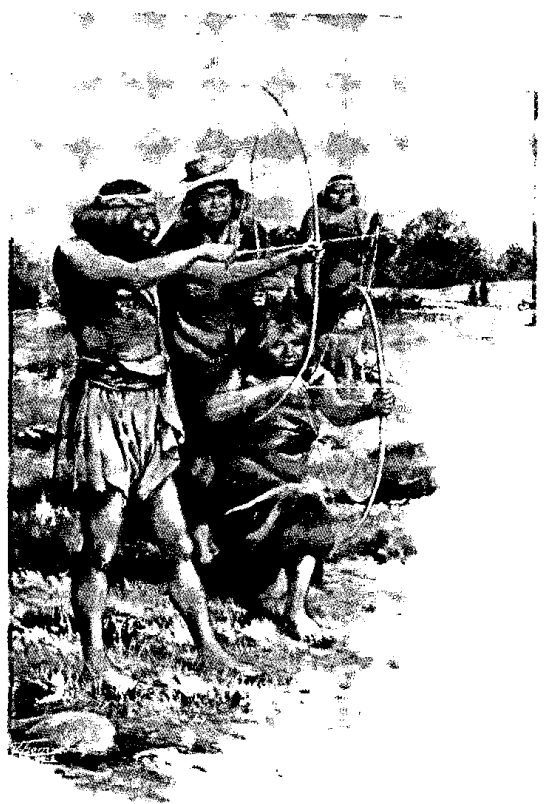

Imagen 2. Publicada en Aragón, "Población", 1902, p. 28.

trabajo aunque siempre lo llevaban a la perfección. A ellos no les inquietaba el porvenir, ni las instituciones nacionales. ${ }^{23}$

Francisco Bulnes los veía como individuos sometidos, desinteresados, estoicos y analfabetas. Ellos mostraban un gran desprecio por la muerte, por la vida, por el oro, por la moral, por el trabajo, por la ciencia, por el dolor y por la esperanza. Si presentaban una gran resistencia física $y$ un vigor inaudito para trasladar enormes pesos en distancias considerables, ello se debía a que habían sido educados para

23 Pimentel, Memoria, 1903, pp. 125, 132. 
servir como "bestias de carga". Aunque los indígenas eran vistos como seres de gran vitalidad con un perfecto estado de salud, lo cierto es que tenían una constitución débil si se los comparaba con los individuos de especies superiores. Sus grandes pasiones eran la religión, la tierra, la libertad y el alcohol. $\mathrm{Ni}$ Bulnes ni Pimentel hicieron referencia a sus características físicas. Aspecto que Agustín Aragón sí se preocupó por rescatar. Su descripción buscaba integrar la parte física con la emocional y la psicológica, lo que mostraba ciertas reminiscencias de la fisonomía, seudociencia que señalaba que las posturas y los rasgos faciales de los individuos podían servir para entender sus cualidades morales y éticas. En este sentido se decía que la apariencia física era un indicador del valor moral de una persona. Es interesante apuntar que estas ideas fueron retomadas por los fotógrafos, quienes buscaban que por medio de una fotografía se pudiera conocer la identidad de la persona retratada. ${ }^{24}$

${ }^{24}$ Poole, Visión, 2000, pp. 138-139, 199; Todorov, Nosotros, 1991, pp. 117, 150; Stolcke, "Sexo", 2000, pp. 34, 39, 44; Debroise, Fuga, 1994, p. 104. Verena Stolcke señala que la "naturalización" de los rasgos culturales o su mezcla con criterios biológicos es lo que se ha denominado "culturalismo biológico". Estas ideas surgieron a fines del siglo XvIII, pero con Gobineau alcanzaron su máximo esplendor. Este autor postulaba que las cualidades morales del individuo estaban determinadas por sus disposiciones físicas, por lo que era vano educar a un individuo, pues no iba a cambiar los hábitos que había heredado. Debroise advierte que la teoría biologicista de la organización social consideraba que los individuos se distinguían por sus actitudes y su vestimenta, factores que servían para identificarlos como parte de una etnia o de una cultura particular. En estos nuevos sistemas de individualización, la fisonomía y la gestualidad se
Ahora bien, Aragón decía que el indígena se caracterizaba por ser de estatura media, de piel morena, las palmas de las manos y las plantas de los pies de color blanco amarillento, frente estrecha, pelo abundante y lacio, ojos grandes, negros y expresivos. En este punto, Aragón hacía notar que la separación de los ojos era más amplia que la que se observaba entre las razas blancas. Su nariz era fea aunque tenía dientes blancos y uniformes. La barba era redonda y el bigote lacio y escaso. El indígena era notable por su resistencia a las condiciones climáticas más severas y por contar con un vigor inagotable que lo hacía trabajar sin descanso. En el plano intelectual, los indígenas eran ineptos para la invención pero aptos para la imitación. Desde el punto de vista psicológico y moral eran afectuosos, serviciales, comedidos, obedientes, serviles, melancólicos, poco impulsivos, bulliciosos, inquietos, turbulentos, crueles y desconfiados. ${ }^{25} \mathrm{El}$ texto de Aragón que formaba parte de México: su evolución social, contenía varias fotografías en las que se mostraba a indígenas y mestizos. Éstas no tenían una relación directa con el texto, y más bien se pueden apreciar como comentarios gráficos independientes que tratan de enfatizar el desarrollo evolutivo diferenciado de los grupos retratados. En buena medida, la fotografía se convertía en un medio de definición de los grupos sociales.

La primera fotografía presentaba a indígenas del estado de Veracruz, mientras

volvieron determinantes. Esta tendencia culminaría a fines del XIX con la frenología de Gall, misma que es un intento de clasificación social y racial etnofisiológica.

${ }^{25}$ Bulnes, Pomenir, s. a., pp. 29-30, 42; Aragón, "Población", 1902, pp. 22-23. 
que la otra hacía lo propio con los del Estado de México (véanse imágenes 3 y 4). ${ }^{26}$ En las dos se muestran notables diferencias. La fotografía de los veracruzanos está vinculada con una mirada antropológica. El fotógrafo buscaba registrar el entorno, los rasgos físicos y la cultura material de los individuos. En la foto se acentúa una situación de atraso que se aprecia no sólo por la choza fabricada con varas y palos, sino también por la forma de vestir (las dos personas van cubiertas con poca ropa y no tienen zapatos) y por el instrumento de trabajo fabricado de madera que uno de los individuos lleva en la mano. En cambio, la imagen que se presenta del segundo grupo muestra la otra cara de la moneda. Este retrato tiene la forma de una tarjeta de visita, y representa a una familia bien vestida y bien "portada" de la campiña nacional. Una de las peculiaridades de esta foto es que tendía a reproducir el estereotipo del indígena mexicano, pues, como señala Patricia Massé, la tarjeta de visita era un medio para definir la pertenencia a un determinado grupo social. ${ }^{27}$ Las dos fotos mostraban que la tarea de integrar a los indígenas al proyecto nacional todavía se encontraba lejos de ser cumplida.

Sin embargo, se tenía la esperanza de que se podía lograr, tal y como lo evidenciaba el caso de los indígenas del Estado de México. Por ello es que se ponía énfasis en la idea de educar al indígena, puesto que se pensaba que ésa era una de las formas que les permitirían integrarse al proyecto de modernidad. Esa tarea tendría

${ }^{26} \mathrm{La}$ fotografía de los indios veracruzanos fue tomada por el fotógrafo francés Briquet.

${ }^{27}$ Massé, Simulacro, 1998, p. 122. que hacerse con prontitud, debido a que la evolución de un pueblo se medía por la conjunción de su crecimiento interno con el externo. Los indígenas se habían manifestado como buenos receptores del conocimiento, lo cual se podía comprobar con los resultados obtenidos por los individuos de esta raza que habían desempeñado cargos públicos. Sin embargo, la igualdad evolutiva no podría llegar mientras no se eliminaran las desigualdades civiles, la esclavitud, el fanatismo, la embriaguez, el raquitismo intelectual y sus anticuadas costumbres e idiomas. Así, Bulnes decía que se les podrían construir escuelas, elevar sus jornales, repartir las tierras, pero estos esfuerzos no darían ningún resultado mientras ellos carecieran de libertad individual. Esta situación retardaría el proceso de constitución de México como nación, entendida ésta como la reunión de hombres con las mismas creencias, dominados por una misma idea y por un mismo fin. ${ }^{28}$

La homogeneidad podría ayudar al desarrollo evolutivo total, mismo que sólo se podría lograr a través del mestizaje. Éste

${ }^{28}$ Pimentel, Memoria, 1903, pp. 131, 133, 136 139; Bulnes, Porvenir, s. a., p. 100; Aragón, "Población", 1902, p. 29; Sierra, Evolución, 1991, pp. 97, 362; González, "Ideas", 1988, pp. 569-570; Kouri, "Interpreting", 2002, p. 87; Hale, Transformación, 1992, p. 363. Esta postura también fue defendida por periódicos católicos como El Tiempo y El Universal, los cuales combatían las ideas del periódico liberal El Siglo XIX acerca del poligenismo y la superioridad racial. Ellos pensaban que los indígenas no eran seres inferiores, pues tenían representantes destacados en la política, en la ciencia y en el arte. De hecho, en El Tiempo se decía que la degradación del indígena era un fenómeno que afectaba a la población mexicana en general. 


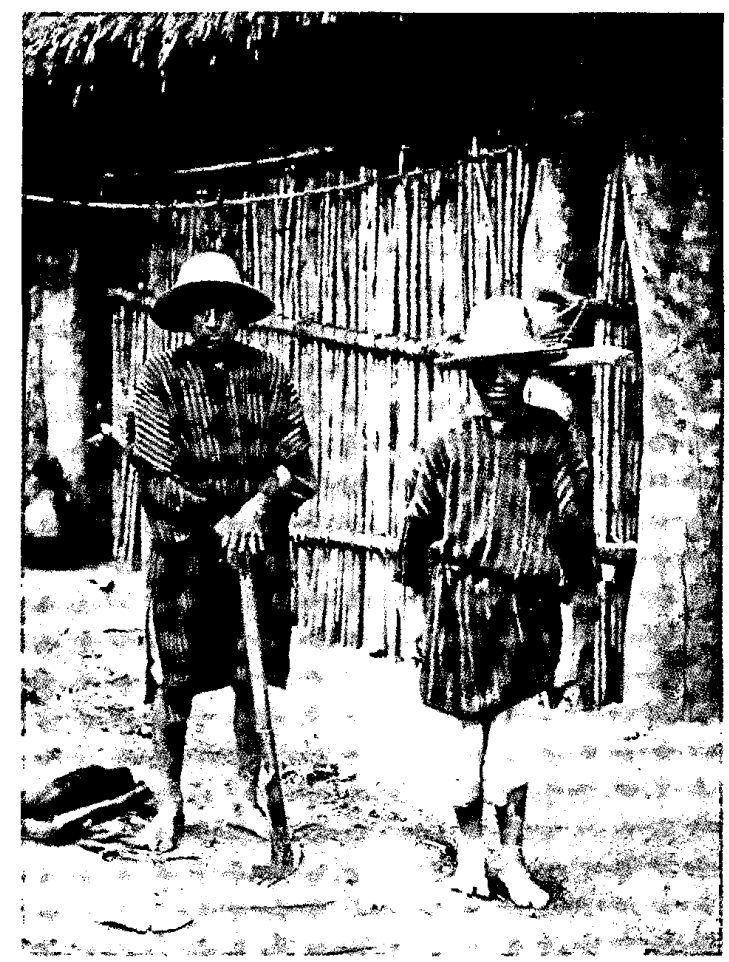

Imagen 3. Publicada en Aragón, "Población", 1902, p. 25.

era el fin último en el que se encontraba la solución del problema indígena. Algunos pensadores europeos consideraban que el mestizaje era la solución ideal para evitar los conflictos que generaba la pluralidad de razas. Por ejemplo, Gobineau sostenía que una sociedad era más sólida si asimilaba diversos grupos en su interior. Sin embargo, ello llevaba implícita una paradoja, pues, desde el punto de vista racial, una sociedad mezclada se con- sideraba débil. No obstante, los pensadores mexicanos creían que el mestizaje no sólo resolvería el problema racial sino también el evolutivo. ${ }^{29}$ Así, la idea del mes-

29 Pimentel, Memoria, 1903, p. 145; Todorov, Nosotros, 1991, pp. 121, 150; Brading, "Patriotismo", 1992, pp. 187-89; König, "Bárbaro", 1998, p. 22; Poole, Visión, 2000, p. 193. Francisco Pimentel pensaba que la transformación a través de la mezcla racial con los inmigrantes extranjeros ayudaría a crear una 


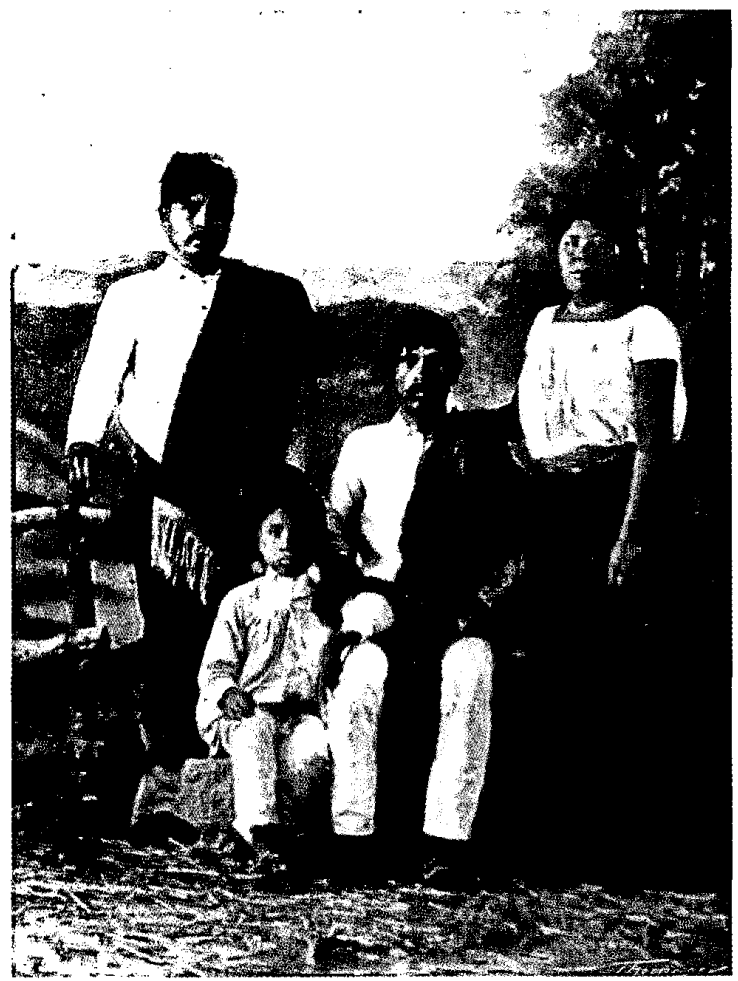

Imagen 4. Publicada en Aragón, "Población", 1902, p. 25.

tizaje como factor de unidad planteaba una separación con respecto a las teorías raciales dominantes en la década de 1880 ,

raza "mixta" o "de transición", la cual no sólo tendría la ventaja de ser producto de la herencia blanca, sino que también conseguiría amalgamar las virtudes de los dos grupos. A diferencia de Pimentel, Ignacio Ramírez e Ignacio Manuel Altamirano creían que la supervivencia de los pueblos indios sería un obstáculo para la integración de la población nacional. en las que se postulaba la idea de la degeneración racial y las consecuencias degenerativas que provocaba la mezcla racial. ${ }^{30}$ Por esta razón, nos ocuparemos en el siguiente apartado de la compleja elaboración de la teoría del mestizaje.

${ }^{30}$ Tenorio, Artilugio, 1998, p. 132. Sobre la teoría de la degeneración véase Urías, Indígena, 2000, p. 77. 
EL MESTIZAJE COMO MOTOR DE LA EVOLUCIÓN Y FACTOR DE UNIDAD NACIONAL

Es difícil precisar con exactitud los inicios de la teoría del mestizaje. Sin embargo, los primeros indicios se pueden encontrar en dos libros que se publicaron con la intención de presentar a México ante el mundo. Tanto en el México y sus alrededores como en Los mexicanos pintados por si mismos, ${ }^{31}$ textos publicados a mediados del siglo XIX debido al fuerte impulso que dieron las casas editoriales a la publicación de estampas costumbristas, se puede apreciar una original presentación del mestizo como el mexicano por antonomasia. Con esto se buscaba dejar de lado las ideas que se habían difundido durante la época colonial respecto a que el mestizaje era una forma de corrupción del cuerpo político, el cual se construía a partir de los grupos sociales que se identificaban en términos de sangre. ${ }^{32}$ Además, se buscaba que la noción de mestizaje funcio-

\footnotetext{
${ }^{31}$ Massé, Simulacro, 1998, p. 55; Debroise, Fuga, 1994, p. 106. México y sus alrededores fue publicado en 1856 por Jean Decaen. El libro tenía ilustraciones de Casimiro Castro y de Ignacio Campillo. En tanto que Los mexicanos pintados por sí mismos fue editado entre 1854 y 1855 por Manuel Munguía. El texto tenía litografías de Hesiquio Iriarte. Massé señala que este libro sólo describía al "bajo pueblo" y al "medio pelo" de la sociedad mexicana. Debroise dice que las series de tipos populares tuvieron un éxito sin precedentes en el siglo XIX.

${ }^{32}$ Victoria, "Imágenes", 1989, p. 144; Lomnitz, "Introducción", en Vicios, 2000, pp. 18, 22. Lomnitz señala que el discurso en torno a las mezclas raciales formaba parte de un repertorio de transgresiones del orden cristiano real. Por ello es que se ponía tanto énfasis en mostrar que la mezcla racial podía producir una descendencia degenerada e idiotizada.
}

nara como un factor de unidad política. Los nuevos grupos políticos liberales que ascendían al poder pretendían convertir al mestizo en el prototipo nacional. Este discurso tendría mayor trascendencia después de la victoria sobre la intervención francesa y el imperio, y fructificaría en el México a través de los siglos, proyecto colectivo dirigido por Vicente Riva Palacio y publicado entre 1884 y 1889 , en el que se planteaba una visión liberal de la historia.

Ésta se construyó a partir de la fusión de distintos elementos históricos y culturales que pretendían representar los rasgos fundamentales de una historia nacional, homogénea, lógica y asimilable para la población en general. La necesidad de establecer la idea del mestizaje como factor esencial de México respondía al proyecto de mostrar que la unidad de razas podía afianzar la estabilidad del país. En este sentido, se explicaba que el desorden y la anarquía del pasado inmediato eran consecuencia de las diferencias raciales de la población. Por ello es que se planteaba que la asimilación de los grupos raciales, como primera condición de la transformación, podía ayudar a consolidar el proyecto civilizatorio que México tenía para el futuro. El origen de los mestizos se encontraba en la época colonial, etapa de la historia que se consideraba de formación. Este hecho no se podía olvidar porque ello significaría, según las palabras de Justo Sierra, la pérdida de "nuestra alma". El contacto que se generó entre españoles e indígenas no sólo había ayudado a impulsar el progreso parcial de la evolución, sino que también había favorecido la mezcla racial de la que surgieron los mestizos. Un grupo que poco a poco empezó a ganar espacios dentro de la sociedad colonial, sobre todo en el ámbito educativo, 
donde comenzaron a destacar por sus amplios conocimientos, ${ }^{33}$ a diferencia de los criollos, que no aprovecharon su posición social, o de los indígenas, que nunca pudieron acceder a la educación.

Así, los mestizos se convirtieron en una "aristocracia del saber" que comprendía a abogados, clérigos y médicos. Es por esta razón que ellos se convirtieron en el germen que iba a impulsar el progreso. Pese a que tenían la superioridad intelectual, los mestizos no lograron sobresalir debido a que las clases dominantes ocupaban los principales puestos en el gobierno. Los mestizos eran un grupo subordinado que contaba con los conocimientos necesarios para dirigir el futuro. Un segundo núcleo de mestizos se desarrolló en el campo. Éstos descendían de los "españoles agricultores" y conformaban un grupo progresista que tenía impedimentos para destacar. La dinámica del sistema colonial y el desprecio racial habían ocasionado que los mestizos ocuparan, junto con los indígenas, el último lugat dentro de la escala social. Si ocupaban esa posición se debía a la falta de elementos que los incentivaran. Esta situación cambió con la guerra de Independencia, pues los mestizos se asociaron con los criollos para lograr la victoria sobre los españoles. Sierra reconocía que los criollos habían llevado el peso de la lucha y los mestizos sólo habían participado como grupo de apoyo, más que de reacción. ${ }^{34}$

${ }^{33}$ Véase Sierra, Evolución, 1991, pp. 56, 96, 119 , 170; Chávez, "Educación", 1902, pp. 487-488; Molina, Grandes, 1981, p. 83; Parra, Sociologia, 1967, p. 95; Flores, Historia, 1982, p. 449; González, "Ideas", 1988, p. 570.

${ }^{34}$ Sierra, Evolución, 1991, pp. 114, 165; Molina, Grandes, 1981, pp. 96-97.
Sin embargo, los mestizos se convirtieron en los principales actores nacionales cuando se dieron a la tarea de conformar un nuevo organismo social. Ellos contaban con los medios para realizar esta gran tarea, pues comprendían los ideales libertarios, poseían el conocimiento y tenían un espíritu curioso, inquieto e inconforme contra la opresión que vivían los grupos sociales desfavorecidos. Los mestizos sabían que la primera tarea que tenían que realizar era desprenderse de la influencia de los otros grupos sociales y, sobre todo, imponerse a ellos. Los defectos que observaban entre los indios y los criollos sólo contribuían a detener el progreso, pues ninguno de estos grupos estaba capacitado para emprender una acción colectiva por la falta de unión y cohesión entre sus miembros. Por ello era necesario eliminar el fanatismo, el autoritarismo y las tradiciones aristocráticas que los criollos habían heredado de los españoles. Además de que tenían que ser destruidos los sentimientos de servilidad y abyección que mostraban los indígenas frente a los otros, lo cual se podía conseguir a través del pensamiento liberal, mismo que mezclaba en su interior el furor antirreligioso, la búsqueda de la igualdad, el escepticismo y un incesante deseo de progreso. ${ }^{35}$

Todo esto sin mencionar que los mestizos estaban en un proceso de rápido crecimiento debido a que la igualdad civil alcanzada con la independencia había favorecido el contacto y el cruzamiento entre razas, situación que los convertía en el grupo social que aglutinaba el mayor porcentaje de la población mexicana. To-

${ }^{35}$ Sierra, Evolución, 1991, pp. 110, 114, 127 128; Chávez, "Educación", 1902, pp. 492-493. 
dos estos factores los convirtieron en uno de los grupos más importantes, lo que produjo un enfrentamiento con los demás grupos sociales. Aunque los mestizos tenían el control cultural, les faltaba controlar el poder político y económico. Para lograr el poder político tenían que enfrentarse en una lucha directa contra los criollos, lucha que se desarrollaría durante buena parte del siglo XIX. Sierra decía que los mestizos triunfaron debido a que los criollos no tenían vínculos de unión. La debilidad de éstos se puso de manifiesto ante el empuje que mostraron los mestizos, primero con el Plan de Ayutla y después en la guerra de Reforma. Además pensaba que estos dos acontecimientos tuvieron el carácter de revoluciones, debido a que ayudaron a transformar al ser social, con lo que aceleraron de manera violenta el proceso evolutivo mexicano. ${ }^{36}$

Sierra reconocía que no todos los mestizos estaban comprometidos con la lucha, ya que muchos de ellos tuvieron que ser obligados a pelear no sólo contra los conservadores, sino también contra los extranjeros. Sin embargo, la inteligente y denodada dirección de Benito Juárez, un indígena que se había identificado con los valores de los mestizos, fue un factor crucial para lograr la victoria y consolidar a éstos como la clase política gobernante. La presidencia de Juárez no sólo significaba la presencia de un gobierno mestizo, sino que también garantizaba la nacionalidad. En este punto es importante señalar que la identificación de Juárez respondía a la necesidad de señalar que el mestizaje no sólo era un factor biológico, sino cul-

${ }^{36}$ Sierra, Evolución, 1991, pp. 251, 286, 324325; Molina, Grandes, 1981, p. 110; Aragón, "Población", 1902, p. 27. tural. Los autores analizados creían que la cultura era la forma más efectiva de integrar a los indígenas al proyecto mestizo de la nación. Ahora bien, Sierra decía que la victoria del mestizo sobre los extranjeros y los criollos había permitido delinear la dirección de la sociedad en el orden moral, intelectual y material. Los mestizos formaban la clase media impulsora de cambios políticos y sociales, aunque no de los económicos, porque la gran propiedad y la industria aún se encontraban en manos de los criollos. Los mestizos sólo tenían pequeñas posesiones que no podían competir con la gran propiedad. ${ }^{37}$

Así, la formación de una clase media en el ámbito económico todavía era una tarea pendiente. En vista de lo anterior, los mestizos de clase media tenían que promover y sostener el progreso en todos los demás órdenes sociales, pues se veía muy difícil destruir los privilegios naturales y legales de los que gozaban los grandes propietarios criollos. Otra de las tareas de la clase media era convertirse en el cimiento de la nación. Ellos tendrían que formar el núcleo de la nueva familia mexicana, misma que, a decir de Andrés Molina Entíquez, ${ }^{38}$ formaría la "nueva burguesía" que tendería a absorber a todos los elementos activos de los grupos inferiores. Para ello tendría que enseñar a los

${ }^{37}$ Molina, Grandes, 1981, pp. 116-117, 125-130.

${ }^{38}$ Andrés Molina Enríquez nació en 1866 en Jilotepec, Estado de México. Ocupó algunos cargos administrativos en su estado natal. Escribió en periódicos como El Imparcial, El Siglo XX, El Partido L,iberal y El Tiempo. Autor de varios estudios históricos y políticos como La cuestión del día. La agricultura nacional (1902); La reforma y Juárez. Estudio bistórico-sociologico (1906); Los grandes problemas de México (1909); El problema de la colonización nacional (1910). 
individuos carentes de carácter la forma en que deberían romper sus cadenas. Cuando se lograra este ideal, México podría avanzar sin ningún obstáculo hacia el pleno desarrollo de la civilización. Andrés Molina estaba convencido de que se había llegado a un momento clave para lograr la evolución de todos los elementos del cuerpo social. El establecimiento de un gobierno sólido, encabezado por un mestizo como Porfirio Díaz, quien había dominado a todos los grupos de acción social, daba la posibilidad de poner mayor. atención al desarrollo de las razas que conformaban la nación, a fin de encauzarlos dentro de una misma lógica evolutiva. ${ }^{39}$

Ello podría servir de base para conformar el ideal de la patria como una unidad. En el pensamiento de Molina se destacaba que no se podía hablar de una patria mientras no se lograra la unión de los diversos componentes que la formaban. Para lograr la unificación de la nacionalidad se tenían que enlazar las condiciones del hogar y la unidad del ideal. ${ }^{40}$

\footnotetext{
${ }^{39}$ Bulnes, Porvenir, s. a., p. 293; Sierra, Evolución, 1991, pp. 98, 397; Molina, Grandes, 1981, p. 192.

40 Todorov, Nosotros, 1991, p. 159. Es difícil saber si Molina conocía los escritos de Gobineau, pues su texto se caracteriza por no citar a los autores con los que trabajó. Sin embargo, en la cuestión del "ideal" se puede percibir cierta influencia de las ideas de este autor. Gobineau pensaba que existían tres momentos del ideal. En el primero, éste no se separaba de lo real, por lo que la población quedaba condenada a la inmovilidad. En el segundo, la población contaba con un ideal y lograba modificar su estado presente, mientras que en el tercero, el ideal actuaba sobre las acciones del pueblo guiándolos a la constitución de una civilización. De acuerdo con este esquema, el pueblo mexicano se encontraba en el segundo punto.
}

La primera se conseguía al resolver el problema de la propiedad, lo que hacía que todos los habitantes tuvieran las mismas condiciones de vida, mientras que la segunda se lograba al fusionar elementos como la religión, el tipo, las costumbres, la lengua, el grado de desartollo evolutivo y los deseos y aspiraciones del grupo. Molina pensaba que el principal problema se encontraba en la constitución de una raza única, lo que permitiría la resolución del tipo y del grado de desarrollo evolutivo. En este sentido, Molina estaba de acuerdo con Telésforo García, quien pensaba que se debería desplazar la idea de raza de "origen común étnico" a la de "comunidad psicológica", que trata de impulsar a las demás colectividades a realizar ideales semejantes. Molina señalaba que la población mexicana estaba compuesta por tres razas: los indígenas, los mestizos y los criollos. Cada una de las razas formaba un grupo y cada grupo tenía en su interior grupos secundarios, lo que daba como resultado una compenetración de razas que mostraban grandes diferencias entre sí. ${ }^{41}$

Los criollos mostraban el mayor grado de coherencia interna, pero buscaban impulsar cambios en la estructura sin tomar en cuenta a las otras razas. Aunque los criollos, sobre todo los "nuevos", eran los más preparados y con el mayor grado de acción social, lo cierto era que ellos no podían convertirse en los dirigentes de la nación por su actitud de desprecio hacia

${ }^{41}$ Molina, Grandes, 1981, pp. 368, 386-91; Molina, Reforma, 1906, pp. 17, 20, 24; González, "Ideas", 1988, p. 570. En La Reforma y Juánz, Molina destacaba que una sociedad homogénea se dividía en capas superpuestas y que las diferencias de grado evolutivo entre cada una de las capas respondía a las diferentes formas de organización. 
los demás grupos. Molina advertía que si los criollos tomaban el poder político se corría el peligro de que éstos cometieran una traición a la patria, debido a que ellos sólo velaban por los intereses extranjeros. Así, los criollos se constituían en un peligro que había que controlar. Es por esta razón que Molina planteaba que era necesaria la unificación de los indios y de los mestizos para alcanzar un alto desarrollo evolutivo y la constitución de una patria. Esto se podía sustentar en la idea de que las dos razas compartían rasgos de naturaleza antropológica y de fuerza selectiva. Desde la perspectiva de Molina, los indios eran el resultado de un largo proceso de selección que les había permitido llegar a constituirse en un organismo superior. Esa superioridad se demostraba en el hecho de que ellos tenían las mejores condiciones para adaptarse a los medios más inhóspitos. ${ }^{42}$

Molina destacaba que la "eficacia de resistencia", como producto de la selección superior de los indígenas, los hacía superiores a las razas blancas, que mostraban una "eficacia de acción" que era el resultado de su evolución superior. Molina creía que la fuerza de los indios y de los mestizos no sólo radicaba en sus condiciones étnicas y selectivas, sino que también se debería buscar en sus hábitos alimenticios, pues el maíz constituía una incomparable base de la nutrición, afirmación con la que buscaba debatir las ideas de Bulnes respecto a que el bajo nivel evolutivo de los pueblos hispanoamericanos se debía a su alimentación sustentada en el maíz. Sin embargo, Molina había seña-

\footnotetext{
${ }^{42}$ Molina, Grandes, 1981, pp. 342-345; Molina, Reforma, 1906, p. 14.
}

lado, unos años antes, que para poder sustituir con éxito al maíz, la población debería llegar a poseer un alto grado de densidad, de aptitud y de riqueza. ${ }^{43} \mathrm{Mo}-$ lina pensaba que para lograr la plena integración de los indígenas era necesario que se fundieran con los mestizos, quienes no constituían una raza diferente, sino que eran indígenas modificados por la sangre española. Para Molina era evidente que los mestizos eran el grupo étnico más interesante del compuesto social. En ellos se apreciaba la unidad de origen, de religión, de tipo, de lengua y de aspiraciones y deseos. Los mestizos exhibían un gran amor por la patria, razón por la cual se los podía ver como el núcleo constitutivo de la verdadera población nacional. Sólo por este hecho, los mestizos deberían permanecer en el gobierno. ${ }^{44}$

Molina pensaba que la pugna por el poder político que enfrentaba a los mestizos contra los criollos se resolvería a favor de los primeros, lo que traería como con-

${ }^{43}$ Bulnes, Pomenir, s. a., pp. 9-40. La teoría racial bulnesiana también proponía que la humanidad basaba su crecimiento en el dominio de una raza por la otra. Véase también Jiménez, Pasión, 2003, pp. $41-42$,

${ }^{44}$ Molina, Grandes, 1981, pp. 351-352, 357358, 404; Molina, Reforma, 1906, p. 25; González, Sociologia, 1985, p. 6; Bulnes, Pomenir, s. a., p. 33. En este punto es interesante señalar que Molina se deslindaba de algunos positivistas que veían a la educación como el medio ideal para borrar las diferencias raciales. Molina no creía que la educación podía ser el procedimiento adecuado para corregir la desigualdad evolutiva. Por el contrario, ella había contribuido al retraso racial en el desarrollo evolutivo. Ello se podía comprobar si se miraba en la historia colonial. El ejemplo más evidente había sido el de los frailes, quienes no pudieron alfabetizar con éxito a los indígenas. 
secuencia la posibilidad de que se llegara a un grado de integración entre los diversos grupos raciales, pues era de vital importancia que los grupos menores se integraran a los mayores. Así, los indígenas y los criollos tendrían que fundirse en la raza mestiza, lo que ayudaría a la unificación del estado evolutivo. Sin embargo, esta tarea no sería sencilla debido al grado de evolución que mostraba cada raza. Los criollos tendrían que pasar por un proceso de involución, mientras que los indígenas adelantarían su desarrollo. Esta opinión muestra que Molina se apegaba a la idea spenceriana de que se podían eliminar algunos estados intermedios para lograr el avance evolutivo. Molina estaba consciente de que no todos los pueblos seguían una trayectoria común en el proceso de desarrollo que iba encaminado al florecimiento cultural, sino que cada pueblo mostraba una trayectoria propia de acuerdo con la resistencia ambiental contra la que se enfrentaba, lo que llevaba a que se entendiera la evolución como expansión progresiva y la involución como concentración selectiva depuradora. ${ }^{45}$

En este sentido, no se podía hablar de atraso, adelanto, inferioridad o superioridad, sino de diversidades infinitas que

\footnotetext{
${ }^{45}$ Molina, Grandes, 1981, pp. 132, 395; Molina, Reforma, 1906; p. 31; Spenser, Primeros, 1905, pp. 280-281; Rumney, Spenser, 1944, pp. 84, 236. Spencer advertía que la mezcla de dos razas podía determinar la relativa heterogeneidad u homogeneidad de las unidades que constituían el agregado social. Así, dos razas que no se mezclaban producían un estado de equilibrio inestable. También había problemas si dos se cruzaban pero no se adaptaban a las instituciones sociales. En cambio, el resultado era positivo si las dos diferían poco en su conformación. Ello llevaba a un progreso en la heterogeneidad.
}

coexistían dentro de la armonía general del conjunto, sin que uno impidiera el desenvolvimiento del otro. Las distintas formas que tomaban las razas podían servir para demostrar la existencia de diferentes etapas de una evolución única, es decir, un pueblo no pasaba por los mismos estadios de desarrollo en orden natural y progresivo, sino que el conjunto podía mostrar que la evolución operaba en la sociedad. Es por esta razón que Molina destacaba que la fusión del criollo con el mestizo sería un retroceso aparente, pues la homogeneidad resultante ofrecería menores dificultades para lograr la aceleración del progreso. No obstante, el establecimiento de la igualdad civil como consecuencia de la forma republicana de gobierno había favorecido el contacto y la mezcla entre las razas como un paso previo a la creación de una sola. Molina estaba convencido de que era necesaria la desaparición de las diferencias entre los grupos que conformaban la nación. Sólo de este modo se podía garantizar el engrandecimiento progresivo de ella, pues la articulación de todos los elementos podía ayudar al equilibrio social. Molina consideraba que en la religión se podía encontrar uno de los factores activos para la constitución de la nacionalidad. Sin embargo, estaba consciente de que para lograr la unificación de la patria se tenían que resolver problemas como la cuestión del origen, misma que buscaría identificar las relaciones entre los grupos como parte de un parentesco real. También se debería buscar la conservación de las costumbres, pues era absurdo tratar de suprimirlas cuando ellas eran el resultado de la selección natural, por lo que respondían a determinadas necesidades fisiológicas y ambientales. Eliminar las costum- 
bres sólo contribuiría a la destrucción de la nación, situación que se podía acelerar si se sustituía el idioma español, puesto que éste había servido como un componente ideal de unificación de la patria. En lo que tocaba a la unión de deseos, propósitos y aspiraciones, Molina creía que ello se podía obtener si se conseguía imponer el carácter del mestizo, el cual combinaba los factores de resistencia con los de acción. Esto marcaba una diferencia con respecto a los indígenas, que mostraban factores de resistencia, y a los criollos, que tenían un carácter impulsivo. Molina insistía que la consolidación de México como nación se tornaba una tarea imprescindible para garantizar su existencia frente a los otros países. Ello se podía conseguir por las condiciones de defensa material y por el desarrollo, unidad y fuerza del espíritu mestizo. ${ }^{46}$

Molina señalaba que la raza mestiza había demostrado ser una raza superior, pues en ella se había logrado conjuntar el ideal patriótico con los mejores aspectos de la selección individual. Aunque advertía que la raza era diferente de la patria, las dos se llegaban a confundir, porque suponían un mismo origen, unas mismas condiciones de vida y un mismo estado orgánico y funcional, lo que las diferenciaba es que la patria era el resultado moral y la raza era el resultado material. Molina pensaba que si se daba el caso de un conflicto con Estados Unidos, el aspeçto racial sería determinante no sólo para resistirlo,

${ }^{46}$ Molina, Grandes, 1981, pp. 396-400, 406$410,419-420,427$. Molina señalaba que otros factores que podían ayudar a la unificación eran la organización de los mestizos, la revisión del sistema nacional de leyes electorales y una reforma de la legislación. sino para vencerlo, puesto que los estadunidenses representaban la "avanzada evolución", mientras que los mestizos constituían la "adelantada evolución". De acuerdo con lo anterior, se puede situar a Molina dentro de aquellas corrientes sociológicas de la segunda mitad del siglo $\mathrm{XIX}^{47}$ en las que se planteaba el concepto de raza como un sujeto biológico y social, que se identificaba por su origen, su parentesco y sus condiciones de vida. Un ente natural en el que encarnaba la lucha por la vida y la selección natural. En este sentido, la lucha de razas se proclamaba como la forma última que cobraba la evolución de los Estados del mundo moderno. El punto final de este conflicto era el predominio de las razas superiores. Y la raza mestiza era una de ellas. ${ }^{48}$

Es importante mencionar que todos los autores estudiados hicieron una descripción del mestizo. Pimentel señalaba que el mestizo era fuerte, dedicado, valiente, confiado, audaz, generoso, leal, pródigo, alegre, jovial y sociable. Tenía una inteligencia aguda y fácil comprensión. Sus vicios se podían desarraigar por medio de la disciplina. Sierra señalaba que el mestizo era un individuo receloso, disimulado y desconfiado. Las determina-

\footnotetext{
${ }^{47}$ Kouri, "Interpreting", 2002, pp. 93-98; Hale, Transformación, 1992, p. 423. Kouri señala que el análisis de Molina Enríquez se fundamentó en cuatro grandes fuentes: el positivismo de Comte y Spencer, el evolucionismo biológico de Darwin y Haeckel, la escuela histórica de Jurisprudencia y la literatura sobre la historia mexicana y la etnología. Sin embargo, Hale dice que el positivismo de Molina fue más comteano que spenceriano, sobre todo en la forma de concebir a la sociedad y al Estado.

${ }^{48}$ Hale, Transformación, 1992, pp. 100, 104, 352-354, 412-416, 432.
} 
ciones que tomaba el mestizo seguían una inversión lógica, pues podía llegar a resoluciones rápidas pero su lenta deliberación interior podía modificar las decisiones que había tomado. Bulnes tenía una actitud ambivalente. Pensaba que los mestizos habían heredado algunos de los "vicios" del español como la rapacidad, la fanfarronería y la poligamia, pero también habían forjado atributos propios como el escepticismo, la liberalidad, el desinterés, el patriotismo, la valentía, la defensa de los derechos del hombre, el nacionalismo, el anticlericalismo, el jacobinismo y el entusiasmo por el progreso y la civilización. Pese a que mostraban buenas facultades intelectuales, el alcohol había impedido que llegaran a alcanzar un alto grado de desarrollo. Genaro Raigosa mencionaba que los mestizos eran hombres ambivalentes que poseían una gran inteligencia y eran apasionados, pero que abandonaban todo sin previo aviso. Este carácter cambiante era producto del clima. ${ }^{49}$

Agustín Aragón decía que el mestizo era ardiente, impresionable y poco prudente. Sus cualidades mentales, que tendían más a la imaginación que a la observación, constituían un impedimento para

49 Pimentel, Memoria, 1903, pp. 146-147; Bulnes, Porvenir, s. a., pp. 36-40, 42, 60; Sierra, Evolyción, 1991, p. 389; Raigosa, "Evolución", 1902, p. 11. Bulnes ponía énfasis en mostrar que los males de los mestizos se debían a la herencia española. Ellos habían dejado vicios como el fanatismo, la pereza, el parasitismo, la ambición, la tiranía, la corrupción, la rebelión y la traición a la patria sólo por conservar sus privilegios, su falta de talento, de aspiraciones, de deseos de progreso y de educación. Con semejante herencia, no resultaba difícil explicar las razones de la inestabilidad. avanzar en la marcha del progreso. Aragón no hizo referencia a los aspectos físicos del mestizo, lo que resulta intrigante pues en su texto se mostraban dos fotografías de mestizos. Estos retratos tenían el formato de tarjeta de visita ${ }^{50}$ y no tenían una relación directa con el texto, pues, al igual que las fotos citadas en páginas anteriores, se las puede apreciar como comentarios gráficos independientes. Las dos personas captadas eran de Yucatán. Una de las razones de su presencia en un libro que trataba de mostrar la imagen de México ante el mundo, podría ser tratar de quitar la idea de que Yucatán era un lugar turbulento. Así, el elemento predominante de esta zona del país no era el indígena rebelde y "salvaje", sino el mestizo educado. Esto se desprende de la composición de las fotos, en las que se muestran personas vistiendo trajes tradicionales, pero con un cierto garbo que busca diferenciarlas del resto de la población (véanse imágenes 5 y 6 ). ${ }^{51}$

En el juego de representaciones visuales presente en el libro México: su evolución social, el mestizo se mostraba superior a

${ }^{50}$ Massé, Simulacro, 1998, pp. 15, 109, 122; Debroise, Fuga, 1994, p. 102. Debroise y Massé señalan que la tarjeta de visita se encontraba asociada con los tipos populares. En tanto que la gente elegante utilizaba con mayor frecuencia el estudio forográfico. Massé considera que la tarjeta de visita era un medio legitimador en el que la apariencia del fotografiado y su actitud definían su pertenencia a un grupo social. Así, una fotografía de cuerpo completo en las tarjetas de visita de los personajes populares tenía una implicación etnográfica, pues se ponía atención al vestido $\mathrm{y}$ a las proporciones del fotografiado.

${ }^{51}$ Un aspecto que se debe destacar en estas fotos es que el fondo es reconstruido. Massé señala que los fotógrafos que realizaban tarjetas de visita construían escenografías, a fin de dar la apariencia de realidad. 


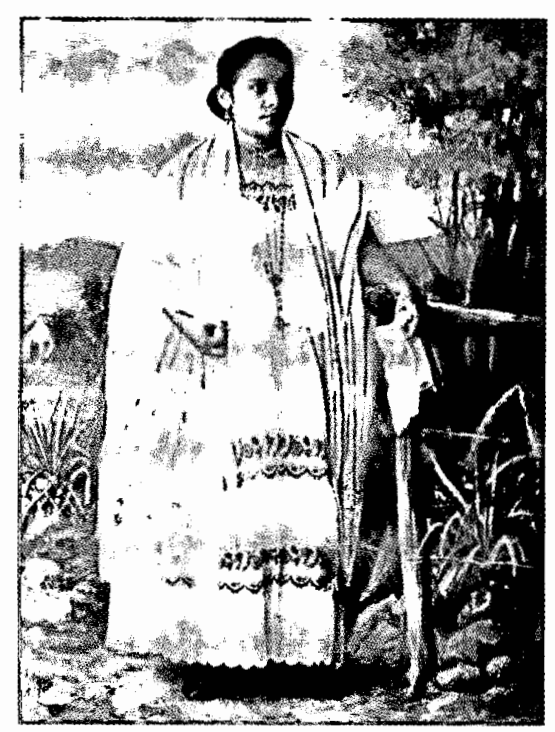

Imagen 5. Publicada en Aragón, "Población", 1902, p. 21.

los demás grupos sociales fotografiados. Aunque es importante mencionar que no aparecía ningún retrato de miembros de los grupos privilegiados. La fotografía transmitía una representación "ideal" del mestizo, misma que servía como un puente para materializar las diferencias que se planteaban respecto a él y a los demás grupos sociales, lo que sugiere que se buscaba implantar, a partir de las imágenes, un conjunto de rasgos concretos con que se pudiera identificar a cada uno de estos grupos. De todos los autores analizados, Molina Enríquez fue el único que utilizó la fisonomía para describir a los mestizos y a los criollos. Así, mostraba que el mestizo medio era de color moreno, de cabello oscuro y rebelde, de barba

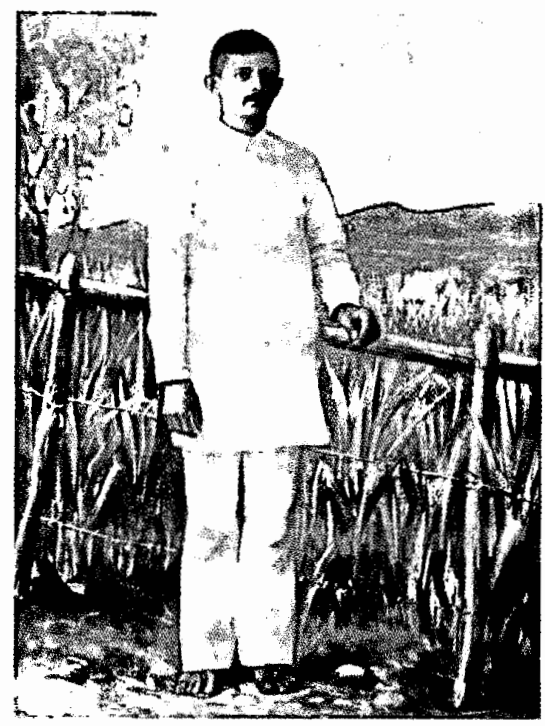

Imagen 6. Publicada en Aragón, "Población", 1902 , p. 23.

escasa, cuerpo tosco y robusto. Esto determinaba su carácter vulgar, rudo, desconfiado, inquieto, impetuoso, terco, fiel, generoso y sufrido. Molina también realizó una descripción de los criollos, a quienes percibía como hombres rubios y de ojos negtos. Su carácter era orgulloso, frívolo, delicado, refinado, cortes y culto. ${ }^{52}$ En este caso, Molina aceptaba la idea del blanco

52 Molina, Grandes, 1981, pp. 106, 110, 112. Molina también realizó una descripción del tipo medio de los extranjeros. De ellos decía que eran rubios claros, de ojos azules, fuertes, aunque no eran groseros tampoco eran finos. Su carácter era laborioso, sobrio, económico, previsor, calculador, codicioso, instruido, sociable y prudente; carecían de sentimientos de autoridad y más bien los animaba un espíritu liberal. 
como el representante más esclarecido de la humanidad, lo que provocaba una paradoja notable en su proyecto, pues reconocía al mestizo como el tipo ideal mexicano, pero admitía su inferioridad frente a los grupos blancos. El que pusiera frente a frente al blanco con el mestizo, se explicaba por su deseo de comprender la distancia evolutiva que los separaba. ${ }^{53}$

Y también por su deseo de mostrar que en México existían blancos, con lo que se podía insertar a la nación dentro de la modernidad y del cosmopolitismo. Aunque los mexicanos no podían demostrar la pureza racial de la moderna población nacional, se hizo un gran énfasis en que la clase alta era blanca, y que México encajaba en el proyecto de modernidad por tener una estructura de clasés bien definida, tal y como lo mostraba Molina en su estudio. Sin embargo, la percepción moliniana fue debatida por Ricardo García Granados, quien señalaba que los mestizos habían demostrado tener mejores cualidades morales y físicas que los estadunidenses y los europeos. La postura de García Granados se explicaba por su afán nacionalista de evidenciar el ser propio del mexicano. Ello se podía lograr a partir de la comparación con los otros. Por ello

\footnotetext{
53 Basave, "Mito", 1992, p. 240; Brading, Mito, 1988, pp. 179, 181, y "Patriotismo", 1992, p. 203. Molina estaba consciente de que, en el ámbito evolucionista europeo, los mestizos no eran considerados seres superiores. De hecho, Basave considera que Molina había hecho un uso arbitrario de los conceptos de Haeckel y Spencer para demostrar la capacidad del mestizo. Por ello es que hizo uso de algunos artificios como la idea de adaptación, misma que pensaba que era el medio que podía ayudar a constituir una raza con un alto nivel evolutivo.
}

es que se tenía que mostrar que el mestizo era mejor que las razas blancas, pues en la búsqueda de lo propio se presentan espacios de delimitación que muestran las diferencias con respecto al otro. ${ }^{54}$ Así, se produjo un proceso de definición del mestizo en oposición al del indígena y al del extranjero. En ella se tendía a concretar un imaginario de identidad nacional, mismo que se podía presentar al mundo como la imagen representativa de México. En síntesis, México era el hombre mestizo.

\section{CONCLUSIONES}

Dentro del proyecto de construcción de la nación moderna mexicana se presentaba el problema de la diversidad racial y cultural. Los intelectuales liberales pensaban que se podía eliminar esa heterogeneidad por medio de la educación y de la mezcla racial. Con ello se lograría la anhelada homogeneidad como un paso previo para conseguir el progreso de México. Lo interesante es que su postura se deslindaba de las teorías raciales que postulaban la eliminación de las razas inferiores. Por el contrario, ellos reconocían la diversidad y pensaban que ésta se podía salvar por medio de la fusión biológica de los grupos. Es por esta razón que el mestizo se convirtió en el representante de ese ideal de unidad e identidad nacional, pues en él se habían amalgamado los valores de las razas indígena y española. Así, el mestizo se convertía en el prototipo ideal del

\footnotetext{
${ }^{54}$ Véase González, "Ideas", 1988, p. 571; Tenorio, Antilugio, 1998, pp. 123, 130, 136; Muñiz, "Identidad", 1993, p. 25; Villoro, Grandes, 1987, pp. 188 190, y Lafaye, "Prolegómenos", 1994, pp. 26-27.
} 
mexicano. Aunque no debemos pasar por alto que la creación de ese prototipo respondía a la necesidad de legitimar al grupo que se encontraba en el poder. Los liberales asociaban al mestizo con ellos mismos. En este marco de referencia, se puede explicar por qué Benito Juárez y Porfirio Díaz eran los representantes del mestizaje. Del segundo sí se podía justificar esta alusión, pero del primero no. Sin embargo, el uso político del pasado tiende a "silenciar" ciertos hechos.

Juárez se convirtió en un mestizo "ideal" debido a la paridad de intereses que tenía con los representantes de este grupo racial. Además de que era el ejemplo más evidente de que el mestizaje se podía lograr por medio de la educación, es decir, el mestizaje se convirtió en un asunto cultural. Por ello, no resulta extraño que esta misma idea fuera usada unos años después por el régimen revolucionario triunfante. La asociación del mestizo con lo mexicano sería una parte fundamental del discurso nacionalista y racista, discurso que tuvo vigencia, por lo menos, hasta los años cuarenta del siglo XX. Ahora bien, en lo referente a la aspiración liberal de incorporar al indígena al proyecto modernizador del país, se puede ver que esta idea adolecía de serios problemas, pues los intelectuales creían que el contacto entre los grupos ayudaría a eliminar las distancias culturales. Fredrik Barth ha mostrado que las diferencias entre los grupos raciales persisten a pesar de los contactos que se generan entre ellos, lo cual se debe a la existencia de categorías étnicas básicas y a la construcción de estructuras de interacción que permiten la persistencia de esas diferencias. Los intelectuales liberales no percibieron este hecho debido a que ellos creían que los grupos indígenas tenían patrones homogéneos de comportamiento. ${ }^{55}$

Es cierto que reconocían ciertas diferencias evolutivas entre ellos, pero concebían a los indígenas como esencias inamovibles que podían cambiar su identidad por medio del contacto cultural con grupos más desarrollados. Aunque su estereotipo del indígena mostraba una aparente unidad de caracteres, lo cierto es que éste no ayudaba a entender las diferencias que existían entre ellos. Y tampoco se daban soluciones concretas para lograr la tan anhelada unidad que se basaba en una idea evolucionista. Es por ello que se buscaba la homogeneidad entre los grupos raciales como un paso previo para alcanzar el siguiente escalón evolutivo. Así, el mestizaje se convirtió en una de las panaceas liberales. Sin embargo, el proyecto de mestizaje cultural y biológico carecía de bases firmes para consolidarse. Pese a que se reconocían los problemas políticos y económicos que retardaban la tan ansiada unidad, ninguno de los pensadores estudiados proponía medidas concretas para ayudar a la integración de todos los grupos que componían el mosaico mexicano. Es por esta razón que se debe entender el mestizaje como un proyecto político de presentación ante el mundo. En este sentido, el México mestizo podía anteponerse al mundo occidental blanco. Y, como pensaba de manera utópica Andrés Molina Enríquez, quizá algún día esa raza desplazaría a la blanca.

ss Barth, Grupos, 1976, pp. 10, 21; Villoro, Grandes, 1987 , p. 118. Villoro señala que a los intelectuales decimonónicos les faltó agudeza para percibir las diferencias que existían en el mundo indígena. 


\section{BibLIOGRAFÍA}

-Anderson, Benedict, "El efecto tranquilizador del fratricidio: o de cómo las naciones imaginan sus genealogías" en Noriega, Nacionalismo, 1992, pp. 83-103.

- Comunidades imaginadas. Reflexiones sobre el origen y la difusión del nacionalismo, FCE, México, 1993 (Colección Popular, 498).

-Aragón, Agustín, "Población actual de México y elementos que la forman. Sus caracteres y su condición social" en Justo Sierra, México: su evolución social, J. Ballescá y Compañía, Sucesor Editor, México, 1902, t. I, pp. 17-31.

-Barth, Fredrik, Los grupos étnicos y sus fronteras, FCE, México, 1976.

-Basave, Agustín, "El mito del mestizo: el pensamiento nacionalista de Andrés Molina Enríquez" en Noriega, Nacionalismo, 1992, pp. 221-258.

-Blanco, José Joaquín, Espejos del siglo Xx: ciudad de México, INAH/CONACULTA/Era, México, 1998.

-Brading, David, "El patriotismo liberal y la reforma mexicana" en Noriega, Nacionalismo, 1992, pp. 179-204.

- Mito y profecía en la bistoria de México, Editorial Vuelta, México, 1988 (Colección La Reflexión).

-Bulnes, Francisco, El porvenir de las naciones latinoamericanas ante las recientes conquistas de Europa y Norteamérica (Estructura y evolución de un continente), El Pensamiento Vivo de América, México, s. a.

-Burke, Peter, Formas de bistoria cultural, Alianza Editorial, Madrid, 1999 (Historia y Geografía. Ensayo, 162).

-Chávez, Ezequiel, "La educación nacional" en Sierra, México, 1902, t. I, vol. II, pp. 468-602.

-Cramaussel, Chantal, "Imagen de México en los relatos de viaje franceses: 1821-1862" en Javier Pérez Siller (coord.), México-Francia. Memoria de una sensibilidad común. Siglos $X I X * X X$,
BUAP/CEMCA/El Colegio de San Luis, México, 1998, pp. 334-363.

-Crespo y Martínez, Gilberto, "La evolución minera" en Sierra, México, 1902, t. I, pp. 49-97.

-Debroise, Olivier, Fuga mexicana. Un recorido por la fotografía en México, CoNACULTA, México, 1994 (Cultura Contemporánea de México).

-Escandón, Patricia, "La historia antigua de México en los textos escolares del siglo XIX", Secuencia. Revista Americana de Ciencias Sociales, Instituto Mora, núm. 10, enero-abril de 1988, México.

-Escobar, Antonio y Teresa Rojas (coords.), La presencia del indigena en la prensa capitalina del siglo XIX. Catálogo de noticias, INI/CIESAS, México, 1992 (Biblioteca Gonzalo Aguirre Beltrán. Serie Índices y Catálogos).

-Ferrer, Manuel y María Bono, Pueblos indigenas y Estado nacional en México en el siglo XIX, IIJ-UNAM, México, 1998 (Estudios Históri$\cos , 79)$.

-Flores y Troncoso, Francisco de Asís, Historia de la medicina en México, IMSs, México, 1982, t. II.

-González Navarro, Moisés, "Las ideas raciales de los científicos, 1890-1910", Historia Mexicana, vol. XXVII, núm. 148, abril-junio de 1988 , pp. 565-583.

- Sociología e bistoria en México (Barreda, Sierra, Parra, Molina Enríquez, Gamio, Caso), El Colegio de México, México, 1985 (Jornadas, 67).

-Hale, Charles A., La transformación del liberalismo en México a fines del siglo XIX, Editorial Vuelta, México, 1992 (Colección La Reflexión).

-Jiménez Marce, Rogelio, "La construcción de una genealogía liberal", Historias, INAH, núm. 51, enero-abril de 2002, México, pp. 25-37.

- La pasión por la polémica. El debate sobre la bistoria en la época de Francisco Bulnes, Instituto Mora, México, 2003.

-König, Hans-Joachim, “¿Bárbaro o símbolo de la libertad? ¿Menor de edad o ciuda- 
dano? Imagen del indio y política indigenista en Hispanoamérica" en Hans-Joachim König, El indio como sujeto y objeto de la bistoria latinoamericana. Pasado y presente, Iberoamericana/Publicaciones del Centro de Estudios Latinoamericanos de la Universidad Católica de Eichstätt, Madrid, 1998 (Serie A. Actas, 18).

-Kouri, Emilio, "Interpreting the Expropiation of Indian Pueblo Lands in Porfirian Mexico: the Unexamined Legacies of Andrés Molina Enríquez", Hispanic American Historical Review, vol. 82, núm. 1, febrero, 2002, pp. 69-117.

-Lafaye, Jacques, "Prolegómenos a todo estudio por venir de la identidad nacional mexicana" en Serge Gruzinski et al., México: identidad y cultura nacional, UAM-Xochimilco, México, 1994, pp. 25-34 (Biblioteca Memoria Mexicana, 3).

-Lomnitz, Claudio (coord.), Vicios públicos, virtudes privadas: la corrupción en México, CIESAS/Porrúa, México, 2000.

-Massé Zendejas, Patricia, Simulacro y elegancia en tarjetas de visita. Fotografías de Cruces y Campa, INAH, México, 1998 (Alquimia).

-Molina Enríquez, Andrés, La reforma y Juárez. Estudio histórico-sociológico, Tipografía de la Viuda de Francisco Díaz de León, México, 1906.

- Los grandes problemas nacionales, Ediciones Era, México, 1981 (Problemas de México).

-Muñiz García, Elsa, "Identidad y cultura en México. Hacia la conformación de un marco teórico conceptual" en Lilia Granillo (coord.), Identidades y nacionalismo: una perspectiva interdisciplinaria, UAM-Azcapotzalco/Gernika, México, 1993, pp. 13-38 (Ensayos, 39).

-Noriega, Cecilia (ed.), El nacionalismo en México, VIII Coloquio de Antropología e Historias Regionales, El Colegio de Michoacán, Zamora, 1992.

-Parra, Porfirio, Sociología de la reforma, Empresas Editoriales, México, 1967 (El Liberalismo Mexicano en Pensamiento y en Acción).
-Peña, Guillermo de la, "El empeño pluralista: la identidad colectiva y la idea de nación en el pensamiento antropológico" en Noriega, Nacionalismo, 1992, pp. 113-139.

-Pimentel, Francisco, Obras completas. Memoria sobre las causas que ban originado la situación actual de la raza indígena de México y medios de remediarla, Tipografía Económica, México, 1903 , t. III.

-Poole, Deborah, Visión, raza y modernidad. Una economía visual del mundo andino de imágenes, Sur Casa de Estudios del Socialismo/Project Counselling Service/Consejería en Proyectos, Lima, 2000.

-Raigosa, Genaro, "La evolución agrícola" en Sierra, México, 1902, t. II, pp. 6-50.

-Rojas, Teresa (coord.), El indio en la prensa nacional mexicana del siglo XIX: catálogo de noticias I, CIESAS/SEP, México, 1987 (Cuadernos de la Casa Chata, 137).

-Rumney, J., Spenser, FCE, México, 1944.

-Sierra, Justo, Obras completas. Evolución política del pueblo mexicano, UNAM, México, 1991, t. XII (Nueva Biblioteca Mexicana, 60).

- México: su evolución social, J. Ballescá y Compañía, Sucesor Editor, México, 1902.

-Smith, Gavin y Gerald Sider (comps.), Between History and Histories, University of Toronto Press, Toronto, 1997.

-Smith, Gavin, "Pandora's History: Central Peruvian Peasants and the Recovering of the Past" en Smith y Sider, History, 1997, pp. 80-87.

-Spencer, Herbert, Los primeros principios, Librería de Fernando Fe, Madrid, 1905.

-Stolcke, Verena, “¿Es el sexo para el género lo que la raza para la etnicidad... y la naturaleza para la sociedad?", Política y Cultura, núm. 14, 2000, pp. 25-60.

-Tenenbaum, Barbara, "Streetwise History: The Paseo de la Reforma and the Porfirian State, 1876-1910" en William H. Beezley, Cheryl English Martin y William E. French, Rituals of Rule, Rituals of Resistence. Public Celebrations and 
Popular Cultura in Mexico, Scholary Resources Books, Wilmington, Delaware, 1994 (Collection Latin American Silhouettes, Studies in History and Culture).

-Tenorio Trillo, Mauricio, Artilugio de la nación moderna. México en las exposiciones universales, 1880-1930, FCE, México, 1998.

-Todorov, Tzvetan, Nosotros y los otros. Reflexión sobre la diversidad humana, Siglo XXI Editores, México, 1991.

-Urías Horcasitas, Beatriz, Indígena y criminal. Interpretaciones del derecho y la antropología en
México, 1871-1921, Departamento de HistoriaUIA, México, 2000.

-Victoria, José Guadalupe, "Imágrenes y palabras: la recuperación de un lenguaje" en Herón Pérez (comp.), Lenguaje y tradición en México, El Colegio de Michoacán, Zamora, 1989.

-Villoro, Luis, Los grandes momentos del indigenismo en México, SEP/FCE, México, 1987 (Lecturas Mexicanas, 103). 